\title{
PEMBERDAYAAN KADER KESEHATAN MELALUI INOVASI TEKNOLOGI EXCELLENT CARE MENUJU MASYARAKAT SEHAT, SEJAHTERA DAN BEBAS COVID-19 DI DESA DARUL AMIN KECAMATAN LAWE ALAS KABUPATEN ACEH TENGGARA
}

\author{
EMPOWERING A HEALTH CARE THROUGH EXCELLENT CARE TECHNOLOGY \\ INNOVATION TOWARDS A HEALTHY, PROSPEROUS AND COVID-19 FREE \\ COMMUNITY IN DARUL AMIN VILLAGE, LAWE ALAS DISTRICT, \\ TENGGARA ACEH REGENCY
}

\author{
Yusnaini \\ STIKes Nurul Hasanah Kutacane \\ Jln. Ahmad Yani No.23, Pulo Kemiri Kecamatan Babussalam, Kabupaten Aceh Tenggara \\ Email: yusnaini84@gmail.com \\ (Diterima 09-03-2021; Disetujui 27-03-2021)
}

\begin{abstract}
ABSTRAK
Desa Darul Amin merupakan desa yang berada di Kecamatan Lawe Alas Kabupaten Aceh Tenggara, Provinsi Aceh, Indonesia. Survey awal selama masa pandemi covid-19 didapatkan beberapa permasalahan berupa masyarakat sering berkumpul bersama bila ada acara/kegiatan, masyarakat merasa khawatir ke tempat layanan kesehatan, prevalensi penyakit tertinggi seperti hipertensi, rematik, asam urat dan diabetes. Adapun hasil pertanian masyarakat berupa jagung, padi, jahe, unyit, lengkuas dan minyak kelapa. Oleh karena itu, pentingnya pengembangan inovasi teknologi excellent care sebagai sarana fasilitas pelayanan kesehatan dan bisnis online untuk mewujudkan masyarakat sehat, sejahtera dan bebas covid-19. Kegiatan yang dilakukan terdiri atas pemberdayaan kader kesehatan, desiminasi ilmu tentang ramuan herbal, pengembangan inovasi teknologi excellent care dan kunjungan tim tenaga kesehatan untuk layanan homecare kepada masyarakat. Kegiatan tersebut bertujuan meningkatkan kesehatan melalui layanan konsultasi dan homecare, mendukung program pemerintah dalam penerapanan social distancing, memberikan peluang bisnis bagi masyarakat dalam mempromosikan ramuan herbal serta mengembangkan Desa Darul Amin sebagai desa percontohan yang memanfaatkan fasilitas pelayanan kesehatan online yang dapat memandirikan masyarakat untuk hidup sehat dan produktif. Kelompok sasaran dalam kegiatan ini adalah masyarakat dan kader di Desa Darul Amin. Adapun hasil capaian kegiatan yaitu masyarakat sudah memanfaatkan layanan kesehatan online, masyarakat sudah mempromosikan ramuan herbalnya melalui www.excellentcare.com, kader dan tenaga kesehatan sudah mendapatkan penghasilan dari layanan homecare.
\end{abstract}

Kata kunci: Pemberdayaan, kader, layanan kesehatan, excellent care

\section{ABSTRACT}

Darul Amin Village is a village located in Lawe Alas District, Southeast Aceh Regency, Aceh Province, Indonesia. The initial survey during the Covid-19 pandemic period found several problems in the form of the community often gathering together when there was an event / activity, the community was worried about health services, the highest prevalence of diseases such as hypertension, rheumatism, gout and diabetes. The community agricultural products are corn, rice, ginger, turmeric, galangal and coconut oil. Therefore, the importance of developing excellent care technology innovation as a means of health service facilities and online businesses to create a healthy, prosperous and free of covid-19 society. Activities carried out consisted of empowering health cadres, disseminating knowledge about herbal ingredients, developing excellent care technology innovations and visiting a team of health workers for homecare services to the community. This activity aims to improve health through consultation and homecare services, support government programs in the application of social distancing, provide business opportunities for the community in promoting herbal concoctions and develop Darul Amin Village as a pilot village that utilizes online health service facilities that can empower people to live healthy and productive. The target groups in this activity are the community and cadres in Darul Amin Village. The results of the activity are that the community has made use of online health services, the community has promoted their herbal ingredients through www.excellentcare.com, cadres and health workers have earned income from homecare services

Keywords: Empowerment, cadres, health services, excellent care 
Pemberdayaan Kader Kesehatan Melalui Inovasi Teknologi Excellent Care Menuju Masyarakat Sehat, Sejahtera dan Bebas Covid-19 di Desa Darul Amin Kecamatan Lawe Alas Kabupaten Aceh Tenggara Yusnaini

\section{PENDAHULUAN}

Saat ini Indonesia tidak hanya menjadi negara dengan penyakit degeneratif tertinggi, namun juga mengalami masa pandemi covid-19. Bila ditinjau di Provinsi Nanggroe Aceh Darussalam khususnya Aceh Tenggara maka memperlihatkan bahwa hasil Riskesdas 2018 prevalensi stroke 4,1 per mil untuk Aceh dan penyakit degeneratif terus mengalami peningkatan. Sedangkan data dari Dinas Kesehatan Kabupaten Aceh Tenggara dengan belum didapatkan masyarakat yang terinfeksi covid-19.

Kutacane merupakan ibu kota dari Kabupaten Aceh Tenggara, Provinsi Aceh, Indonesia. Wilayah Kabupaten Aceh Tenggara (Agara) terletak di ketinggian 25-1.000 meter di atas permukaan laut, berupa daerah perbukitan dan pengunungan. Sebagian kawasannya merupakan daerah suaka alam Taman Nasional Gunung Leuser. Kabupaten Aceh Tenggara terdiri atas enam belas kecamatan yaitu Lawe Alas, Sigala-Gala, Babul Makmur, Bambel, Babussalam, Badar, Darul Hasanah, Lawe Bulan, Bukit Tusam, Semadam dan Babul Rahmah, Deleng Pokhkisen, Tanoh Alas, Leuser, Ketambe, Babul Makmur dan Lawe Sumur. Peta lokasi Kutacane bisa dilihat pada Gambar 1.

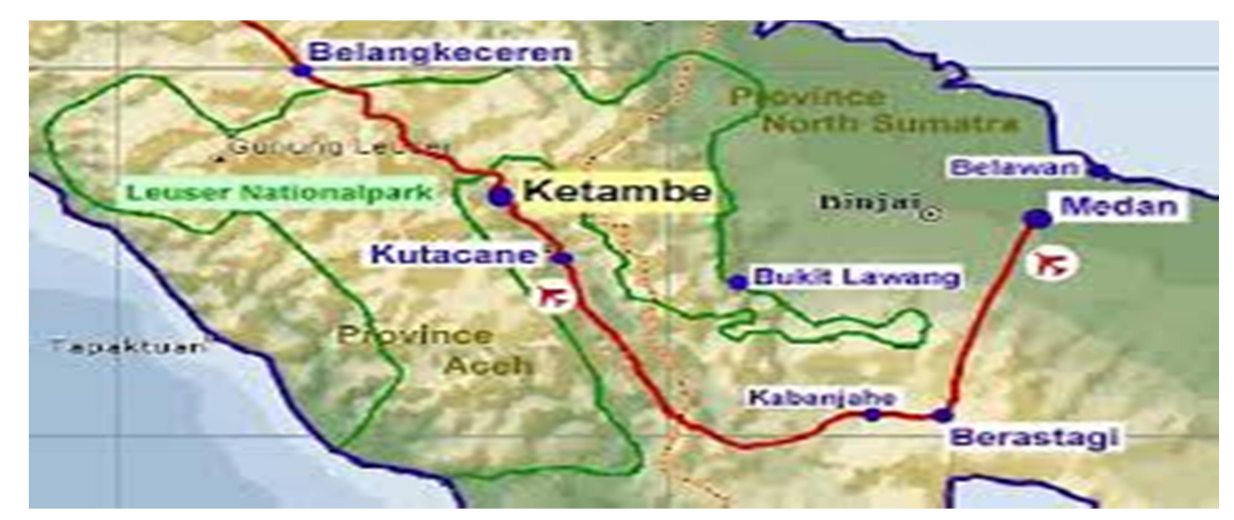

Gambar 1. Lokasi Kutacane (Sumber: Google Map)

Beberapa tradisi dan budaya Aceh Tenggara yaitu "pemamanan", sebuah adat pesta, akikah anak, sunatan dan saat orang meninggalakan dihidangkan makanan yang tinggi zat lemak seperti daging, telur asin, dan sayur yang semuanya dimasak dengan santan. Budaya ini ikut mendukung memperkuat peningkatan penyakit degeneratif di Aceh Tenggara.

Saat ini dunia internasional menghadapi wabah infeksi coronavirus atau dikenal dengan covid-19. Mematuhi pedoman kesehatan umum sangat penting untuk mempertahankan kekebalan yang lebih kuat untuk melawan infeksi dan perlindungan dari bahaya lingkungan lainnya. Krisis coronavirus tidak hanya dapat ditandai sebagai periode 
mengganggu ketidakstabilan, ketidakpastian, dan bahaya; tetapi juga dapat dianggap sebagai periode percepatan difusi teknologi digital.

Penggunaan teknologi digital merupakan kunci dalam upaya untuk memutuskan penyebaran virus covid-19. Menurut Le, Chang, Chang, \& Chen (2019), terdapat lebih dari 5.000 aplikasi layanan kesehatan menggunakan teknologi digital. Solano-Lorente, Martinez-Caro, \& Cegarra-Navarro (2013), menyatakan bahwa pengembangan layanan kesehatan online harus dapat mengintegrasikan kemajuan teknologi digital dan ilmu pengetahuan tentang kesehatan. Loria (2010) mengidentifikasi penerimaan layanan kesehatan online ditentukan oleh kesesuaian layanan dengan kebutuhan masyarakat dan kepercayaan pada layanan pemberi. Layanan kesehatan perlu dikembangkan menggunakan teknologi digital.

Penggunaan kemajuan digital dalam layanan kesehatan sangat memberikan manfaat. Studi Anshari \& Almunawar (2016) menunjukkan bahwa layanan kesehatan online dapat meningkatkan kepercayaan diri dan kepuasan pasien. Menurut Crotty \& Slack (2016), layanan kesehatan berpotensi lebih optimal membantu pasien, mendukung keterlibatan keluarga dalam perawatan pasien dan memberikan kemudahan penggunaan layanan kesehatan sesuai dengan kebutuhan pasien.

Website Excellent Care merupakan suatu bentuk pelayanan kesehatan online, dimana masyarakat menggunakan untuk memilih jenis pelayanan keperawatan, khususnya berkaitan dengan gejala penyakit covid-19 yang sedang mewabah saat ini. Website Excellent Care menyediakan informasi kesehatan yang terkini, memfasilitasi masyarakat untuk konsultasi masalah kesehatan dan menyediakan jasa kunjungan untuk homecare. Website Excellent Care mendukung program pemerintah dalam social distancing, sehingga masyarakat yang mengalami keluhan masalah kesehatan tidak langsung kontak dengan individu lainnya dan menghindari penyebaran penyakit menular.

Website Excellent Care melibatkan kader kesehatan yang berperan untuk membantu masyarakat mendapatkan penangganan keluhan masalah kesehatannya. Penetapan kader kesehatan dipilih dari anggota masyarakat desa yang memiliki pengetahuan, kemauan dan kemampuan untuk menggerakkan masyarakat berpartisipasi dalam pemberdayaan masyarakat untuk hidup sehat, sejahtera dan bebas dari covid-19. Kader kesehatan akan diberikan pelatihan atau pembinaan terkait operasional website excellent care dan proses koordinasi layanan kesehatan dalam website Excellent Care. Kader kesehatan akan melakukan kunjungan tiap minggu dalam mengarahkan masyarakat memanfaatkan website Excellent Care. Bila masyarakat menginginkan adanya kunjungan tenaga kesehatan untuk 
Pemberdayaan Kader Kesehatan Melalui Inovasi Teknologi Excellent Care Menuju Masyarakat Sehat, Sejahtera dan Bebas Covid-19 di Desa Darul Amin Kecamatan Lawe Alas Kabupaten Aceh Tenggara Yusnaini

homecare, maka kader kesehatan desa melakukan pendampingan kunjungan tenaga kesehatan di saat itu juga. Hal ini untuk memudahkan kader kesehatan untuk mengetahui tindakan yang diberikan kepada masyarakat dan mengevaluasi kondisi kesehatan masyarakat.

Website Excellent Care memberikan peluang bagi masyarakat untuk mempromosikan ramuan herbal yang berfungsi bagi kesehatan masyarakat. Ramuan herbal yang dipromosikan yang tersedia di Desa Lawe Alas Kabupaten Aceh Tenggara dan telah resmi disahkan oleh Badan Pengawas Obat dan Makanan. Website Excellent Care memiliki keunggulan yang berfokus kepada peningkatan kesehatan dan kesejahteraan masyarakat.

Studi pendahuluan di Desa Darul Amin Kecamatan Lawe Alas Kabupaten Aceh Tenggara didapatkan bahwa: 1) Sebagian besar masyarakat Desa Darul Amin bekerja sebagai petani dan peternak. Salah satu hasil pertanian masyarakat yaitu berupa rempahrempah seperti jahe, kunyit, kemiri, jeruk nipis dan masih banyak yang lainnya yang dapat dijadikan ramuan herbal; 2) Ketersediaan posyandu sudah terlaksana dengan baik untuk balita, sedangkan posyandu untuk lansia belum tersedia; 3) Kebutuhan gizi lansia masih kurang menjadi perhatian; 4) Prevalensi penyakit yang diderita masyarakat lebih kepada penyakit degeneratif seperti hipertensi, diabetes mellitus dan nyeri persendiaan; 5) Masyarakat Desa Darul Amin tidak ada yang terinfeksi covid-19; dan 6) Kegiatan masyarakat di Desa Darul Amin masih sama baik sebelum maupun saat masa pandemi covid-19.

Berdasarkan latar belakang di atas, maka masalah yang akan dibahas dalam program ini adalah: Pertama, bagaimana pengembangan Inovasi Teknologi Excellent Care menjadi homecare online untuk meningkatkan kesehatan masyarakat di Desa Darul Amin Kecamatan Lawe Alas Kabupaten Aceh Tenggara. Kedua, bagaimana cara memberdayakan kader kesehatan menggunakan Inovasi Teknologi Excellent Care untuk mendukung kesehatan, kesejahteraan dan Bebas Covid-19 di Desa Darul Amin Kecamatan Lawe Alas Kabupaten Aceh Tenggara. Ketiga, bagaimana cara mempromosikan dan mempublikasikan ramuan herbal melalui Inovasi Teknologi Excellent Care yang bernilai bisnis bagi masyarakat di Desa Darul Amin Kecamatan Lawe Alas Kabupaten Aceh Tenggara.

Pengabdian masyarakat ini bertujuan meningkatkan kesehatan dengan menyediakan sumber informasi kesehatan terkini, kemudahan konsultasi dan memfasilitasi jasa homecare melalui website excellent care di Desa Darul Amin Kecamatan Lawe Alas 
Kabupaten Aceh Tenggara. Selain itu, juga memberikan peluang bagi kader kesehatan untuk mendapatkan keterampilan dan penghasilan melalui pengelolaan penjualan ramuan herbal di website excellent care.

\section{BAHAN DAN METODE}

Kegiatan pegabdian masyarakat dilaksanakan di Desa Darul Amin Kecamatan Lawe Alas Kabupaten Aceh Tenggara selama 3 (tiga) bulan dimulai dari tanggal 2 September sampai 25 November 2020 dengan melibatkan kepala desa, kader, 10 orang tenaga kesehatan dan 13 orang mahasiswa STIKes Nurul Hasanah Kutacane.

Metode pengabdian masyarakat ini mencakup;

1. Survei awal

Survei awal di Desa Darul Amin Kecamatan Lawe Alas telah dilakukan untuk mengidentifikasi kondisi masyarakat, animo masyarakat menggunakan fasilitas kesehatan di Puskesmas wilayah kerja Lawe Alas, prevalensi penyakit tertinggi dan hasil pertanian berupa tanaman obat yang dapat dijadikan ramuan herbal.

2. Identifikasi masalah

Berdasarkan survey awal didapatkan bahwa masyarakat desa Darul Amin sangat antusias dalam semangat gotong royongnya, hal ini tergambarkan saat ada pesta penikahan/pemamanan, aqiqah dan kegiatan lainnya maka masyarakat setempat ikut membantu mempersiapkan pesta dan menyumbangkan uangnya. Sebelum keadaan Indonesia mengalami pandemi covid 19, masyarakat yang menderita penyakit akan memanfaatkan fasilitas kesehatan yaitu Puskesmas. Namun, saat ini masyarakat merasa khawatir dengan penyebaran covid-19. Menurut laporan dari petugas Puskesmas wilayah kerja Lawe Alas, prevalensi penyakit tertinggi di Desa Darul Amin yaitu hipertensi, diabetes mellitus dan diare pada anak-anak. Adapun hasil pertanian masyarakat tersebut berupa jagung, padi, jahe, kunyit, lengkuas, minyak kelapa dan lain-lain.

3. Analisis Kebutuhan

Hasil identifikasi masalah menunjukkan bahwa penting pengembangan inovasi teknologi excellent care sebagai sarana fasilitas pelayanan kesehatan dan bisnis online untuk mewujudkan masyarakat sehat, sejahtera dan bebas covid-19.

4. Penetapan Khalayak Sasaran

Adapun yang menjadi khalayak sasaran dalam kegiatan ini adalah kader kesehatan dan masyarakat Desa Darul Amin Kecamatan Lawe Alas Kabupaten Aceh Tenggara. 
Pemberdayaan Kader Kesehatan Melalui Inovasi Teknologi Excellent Care Menuju Masyarakat Sehat, Sejahtera dan Bebas Covid-19 di Desa Darul Amin Kecamatan Lawe Alas Kabupaten Aceh Tenggara

Penetapan kader kesehatan berasal dari anggota masyarakat Desa Darul Amin Kecamatan Lawe Alas Kabupaten Aceh Tenggara yang memiliki pengetahuan, kemauan dan kemampuan untuk menggerakkan masyarakat berpartisipasi dalam pemberdayaan masyarakat untuk hidup sehat, sejahtera dan bebas dari covid-19.

5. Pelaksanaan Program

Pelaksanaan program pemberdayaan kader kesehatan melalui inovasi teknologi excellent care, antara lain:

a. Sosialisasi Program

Sosialisasi program pemberdayaan kader kesehatan di Desa Darul Amin Kecamatan Lawe Alas Kabupaten Aceh Tenggara dilakukan bertujuan untuk memberikan gambaran program yang akan diimplementasikan. Sehingga semua pihak yang terlibat dalam program ini mempunyai persepsi yang sama dalam mewujudkan masyarakat sehat, sejahtera dan bebas covid-19.

b. Pengembangan Website Excellent Care

Website Excellent Care dikembangkan ke dalam tiga kategori, antara lain berupa; 1) Artikel, menyediakan informasi kesehatan terkini; 2) konsultasi kesehatan; 3) home care; dan 4) produk ramuan herbal yang di produksi masyarakat Desa Darul Amin.

c. Pembentukan dan pembinaan kader kesehatan tentang operasional excellent care Pembentukan kader kesehatan ditetapkan dari anggota masyarakat desa Darul Amin yang memiliki pengetahuan, kemauan dan kemampuan untuk menggerakkan masyarakat berpartisipasi dalam pemberdayaan masyarakat.

Pembinaan kader kesehatan dilakukan dengan memberikan pemahaman tentang website excellent care meliputi isi (content), operasional dan pelaksanaan di lapangan dalam memberdayakan masyarakat untuk memanfaatkan fasilitas pelayanan kesehatan dan bisnis online.

d. Desiminasi ilmu tentang ramuan herbal yang dapat menjadi bisnis online

Desiminasi ilmu diberikan kepada masyarakat Desa Darul Amin tentang jenis ramuan herbal, manfaatnya, serta cara menasukkan (insert) ke dalam aplikasi.

e. Simulasi pengunaan website excellent care di Desa Darul Amin

Simulasi penggunaan website excellent care dimulai dari membuka website bagi masyarakat yang memiliki laptop atau handphone bagi masyarakat yang tidak memiliki laptop, selanjutnya kader kesehatan menjelaskan cara pemanfaatan fasilitas layanan kesehatan dan bisnis online. 
6. Strategi pembinaan Khalayak Sasaran

Strategi pembinaan khalayak sasaran berfokus pada prosedur penggunaan website excellent care untuk fasilitas pelayanan kesehatan, koordinasi promosi ramuan herbal online dan pencatatan-pelaporan pemanfaatan aplikasi dan memonitoring keberlangsungan-keberlanjutan program.

7. Perintisan Kemitraan

Pelaksanaan program ini dilaksanakan melalui pernyataan kesediaan kepala desa atau penghulu desa Darul Amin sebagai mitra.

\section{HASIL DAN PEMBAHASAN}

Adapun hasil dari kegiatan pengabdian masyarakat yang telah dilaksanakan di Desa

Darul Amin Kecamatan Lawe Alas Kabupaten Aceh Tenggara, diuraikan sebagai berikut:

1. Kegiatan pelaksanaan pemberdayaan kader kesehatan

Mengkonfirmasi Kepala Desa tentang pelaksanaan kegiatan pengabdian masyarakat di Desa Darul Amin Kecamatan Lawe Alas Kabupaten Aceh Tenggara, merekrut atau pembentukan kader kesehatan dan melakukan sosialisasi program pemberdayaan kader kesehatan melalui inovasi excellent care.

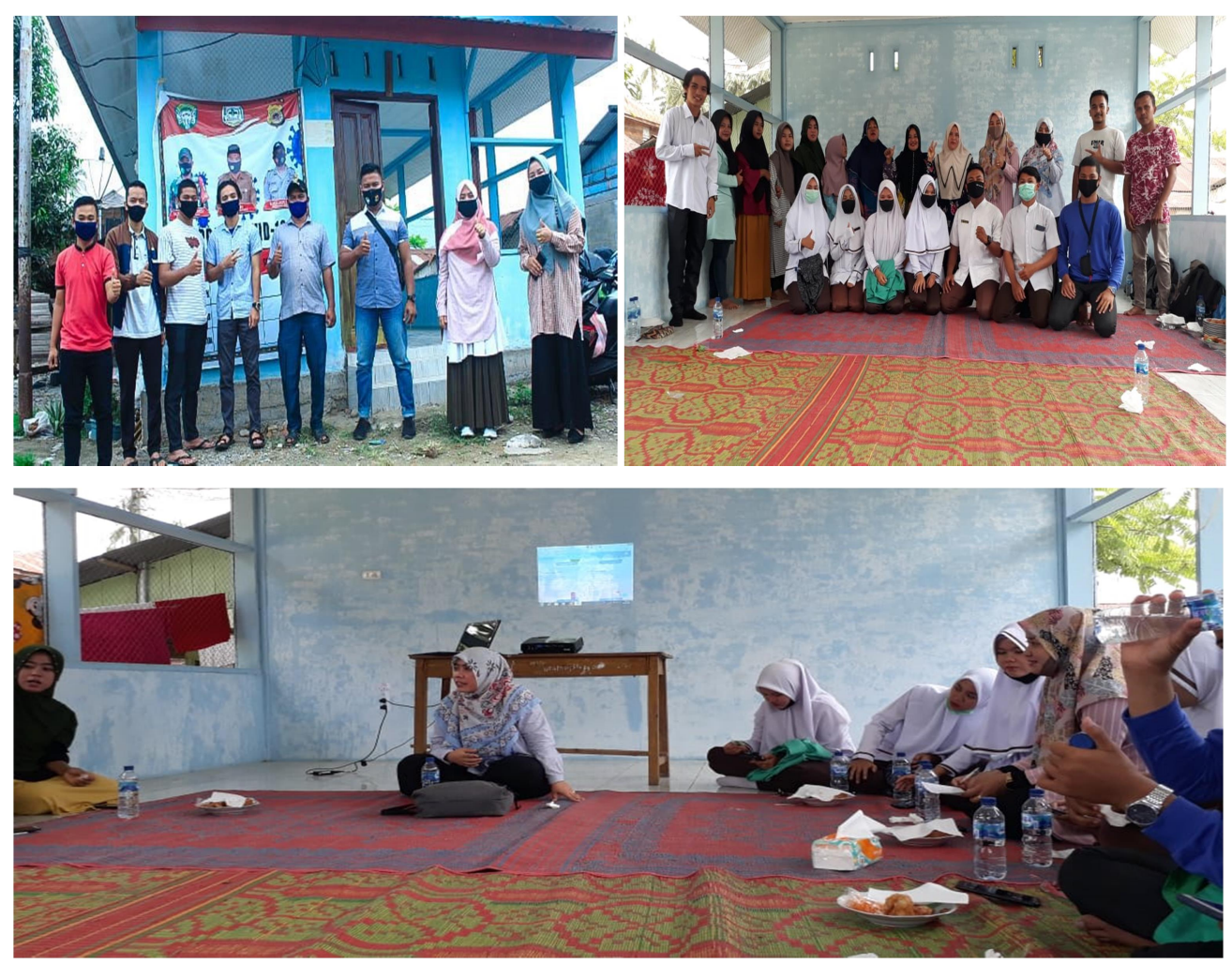

Gambar 2. Pemberdayaan Kader Kesehatan 
Pemberdayaan Kader Kesehatan Melalui Inovasi Teknologi Excellent Care Menuju Masyarakat Sehat, Sejahtera dan Bebas Covid-19 di Desa Darul Amin Kecamatan Lawe Alas Kabupaten Aceh Tenggara Yusnaini

2. Kegiatan pelaksanaan desiminasi ilmu tentang ramuan herbal Mempersiapkan alat dan bahan (jahe, minyak kelapa, parutan, kassa) yang diperlukan untuk desiminasi ilmu ramuan herbal, mengkonfirmasi kader kesehatan untuk pelaksanaan desiminasi ilmu ramuan herbal, dan mensosialisasi ramuan herbal yang dapat dipromosikan di website excellent care, serta simulasi cara membuat ramuan herbal kepada masyarakat Desa Darul Amin.
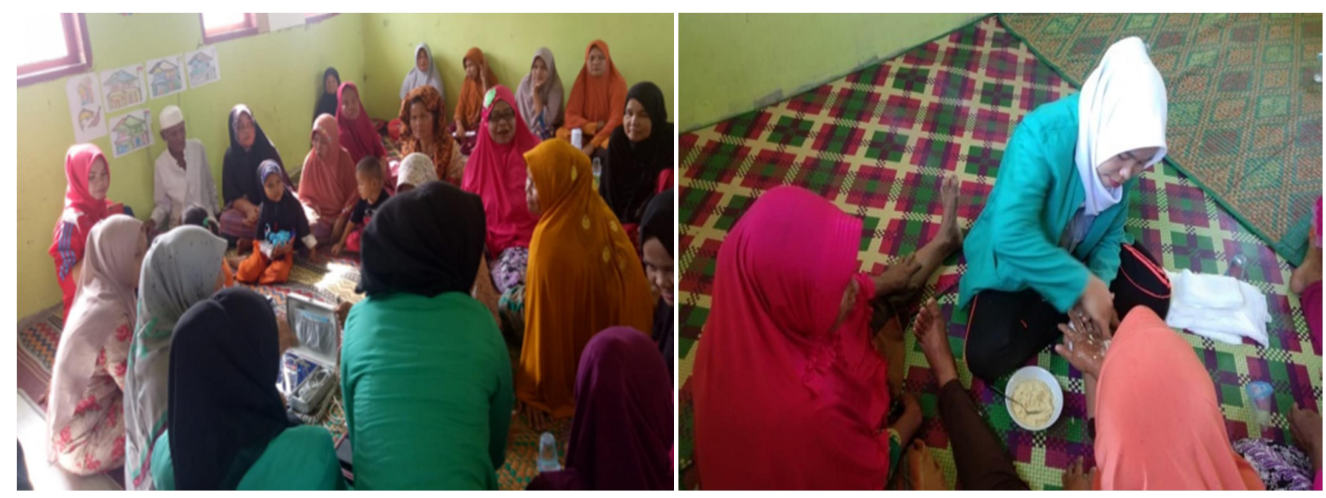

Gambar 3. Desiminasi Ilmu tentang Ramuan Herbal

3. Kegiatan pelaksanaan pengembangan Inovasi Teknologi Excellent Care Mempersiapkan kebutuhan untuk desain homecare online excellent care berupa: artikel (informasi atau masalah kesehatan di masyarakat), menentukan jenis penyakit degeneratif, nutrisi pada lansia dan covid-19 untuk konsultasi kesehatan, memilih tindakan yang akan dilakukan untuk homecare (keluhan atau masalah kesehatan pada penyakit degeneratif dan nutrisi pada lansia), serta mengidentifikasi produk ramuan herbal yang akan dijual. Selanjutnya, mengkonfirmasi dan berkoordinasi kepada web developer untuk mendesain website excellent care.

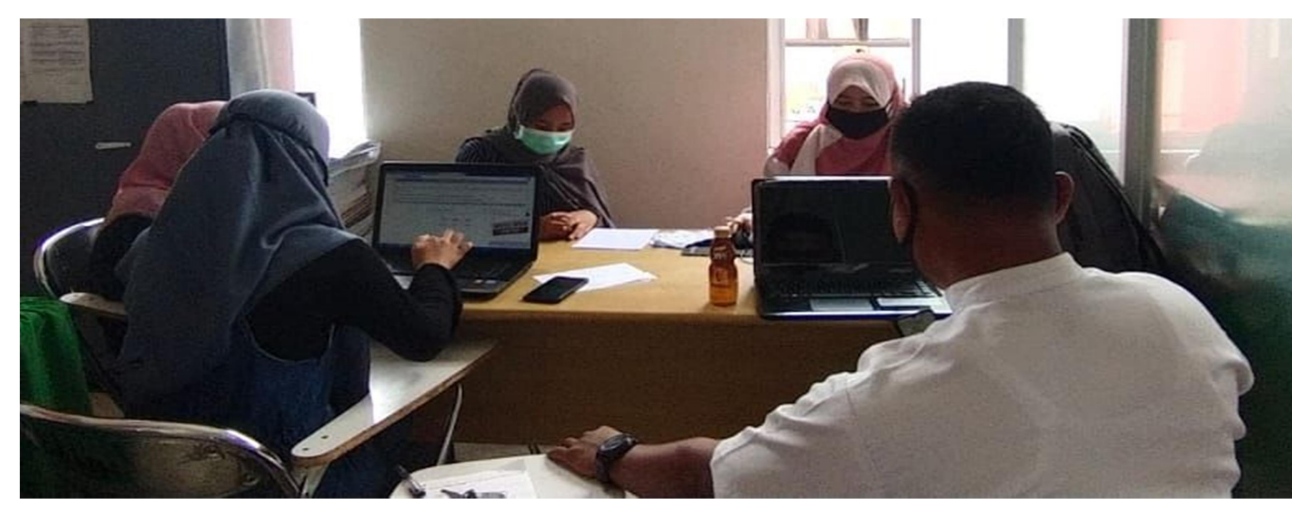

Gambar 3. Pengembangan Inovasi Teknologi Excellent Care 
4. Kegiatan pelaksanaan simulasi penggunaan website excellent care

Persiapan simulasi penggunaan website excellent care, melakukan simulasi penggunaan website excellent care "www.excellentcare.id", mengisi kouta internet kepada tim dan kader kesehatan, serta mendokumentasikan kegiatan simulasi penggunaan website excellent care.

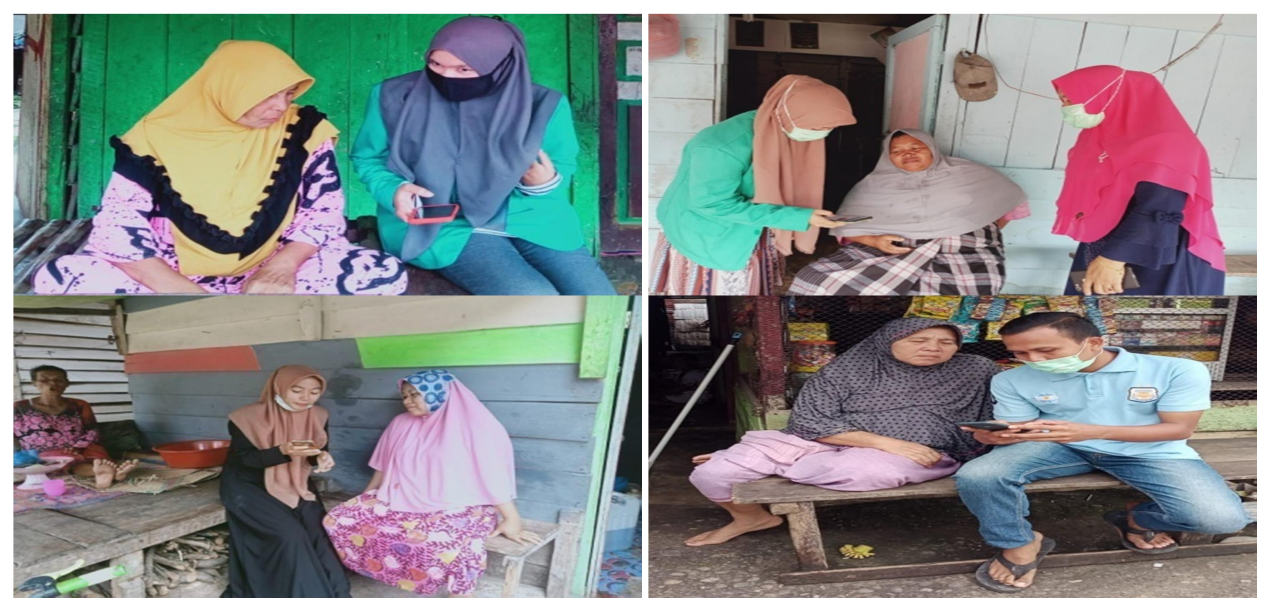

Gambar 4. Simulasi Penggunaan Website Excellent Care

5. Kegiatan pelaksanaan kunjungan Tim homecare ke Masyarakat

Persiapan alat dan bahan (cek glukosa, asam urat dan kolesterol, tensimeter, spigmanometer, masker, kapas, alcohol, handscoon) untuk pelaksanaan homecare kepada masyarakat, mengkonfirmasi tenaga kesehatan yang dapat memberikan jasa konsultasi dan tindakan homecare kepada masyarakat dan memberikan layanan homecare kepada masyarakat didampingi oleh kader kesehatan.

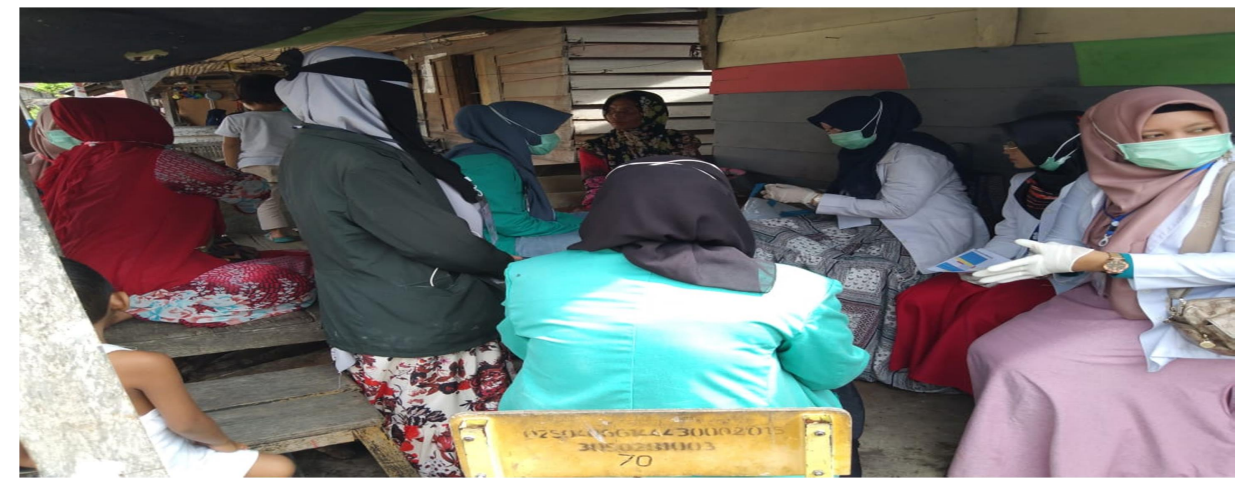

Gambar 5. kunjungan Tim Homecare ke Masyarakat

Kegiatan pengabdian masyarakat melalui inovasi teknologi excellent care memberikan dampak yang positif baik bagi masyarakat, kader maupun tenaga kesehatan antara lain: 
Pemberdayaan Kader Kesehatan Melalui Inovasi Teknologi Excellent Care Menuju Masyarakat Sehat, Sejahtera dan Bebas Covid-19 di Desa Darul Amin Kecamatan Lawe Alas Kabupaten Aceh Tenggara

Yusnaini

1. Ada 54\% masyarakat dari total keseluruhan 123 orang yang dipromosikan layanan excellent care sudah memanfaatkan website excellent care menjadi fasilitas pelayanan kesehatan online yang efektif dan efisien untuk layanan konsultasi dan homecare.

2. Masyarakat mempromosikan ramuan herbalnya melalui website excellent care.

3. Sebelum pelaksanaan layanan homecare, kader dan tenaga kesehatan hanya mendapatkan honor dari pekerjaannya masing-masing. Setelah layanan homecare dipromosikan kepada masyarakat maka pemesanan layanan kesehatan (homecare) melalui www.excellentcare.id dilakukan secara online. Hal ini memberikan penambahan ekonomi sebesar $20 \%$ dari penghasilannya sehari-hari.

4. Adanya keterlibatan alumni, rekan mahasiswa serta dosen dalam kegiatan pengabdian masyarakat ini.

\section{KESIMPULAN DAN SARAN}

Kegiatan pemberdayaan kader kesehatan melalui inovasi teknologi excellent care menuju masyarakat sehat, sejahtera dan bebas Covid-19 telah dilaksanakan di Desa Darul Amin Kecamatan Lawe Alas Kabupaten Aceh Tenggara mencakup pemberdayaan kader kesehatan, desiminasi ilmu tentang ramuan herbal, pengembangan inovasi teknologi excellent care, simulasi penggunaan website excellent care dan kunjungan tim homecare. Adapun capaian dari pelaksanaan kegiatan tersebut berupa masyarakat sudah memanfaatkan layanan kesehatan online, masyarakat sudah mempromosikan ramuan herbalnya melalui www.excellentcare.com, serta kader dan tenaga kesehatan sudah mendapatkan penghasilan dari layanan homecare.

\section{UCAPAN TERIMAKASIH}

Kegiatan pengabdian masyarakat ini merupakan suatu bentuk pelaksanaan Tri Dharma Perguruan Tinggi. Kami mengucapkan terima kasih kepada tenaga kesehatan, kepala desa, kader, masyarakat dan mahasiswa atas kontribusi atas kesuksesan terselenggaranya pengabdian masyarakat ini.

\section{DAFTAR PUSTAKA}

Anshari, M., \& Almunawar, M. N. (2016). Mobile Health (mHealth) Services and Online Health Educators. Biomedical Informatics Insights, 8, BII.S35388. https://doi.org/10.4137/bii.s35388

Crotty, B. H., \& Slack, W. V. (2016). Designing online health services for patients. Israel Journal of Health Policy Research, 5(1), 1-4. https://doi.org/10.1186/s13584-016- 
0082-7

Le, W., Chang, P. Y., Chang, Y. W., \& Chen, J. (2019). Why do patients move from online health platforms to hospitals? The perspectives of fairness theory and brand extension theory. International Journal of Environmental Research and Public Health, 16(19). https://doi.org/10.3390/ijerph16193755

Loria. (2010). Acceptance of Swedish e-health services. Journal of Multidisciplinary Healthcare, 55. https://doi.org/10.2147/jmdh.s9159

Solano-Lorente, M., Martinez-Caro, E., \& Cegarra- Navarro, J. G. (2013). Designing a framework to develop eLoyalty for online healthcare services. Electronic Journal of Knowledge Management, 11(1), 107-115. Retrieved from http://ovidsp.ovid.com/ovidweb.cgi?T $=J S \& P A G E=$ reference $\& D=$ psyc10\&NEWS $=$ $\mathrm{N} \& A N=2013-27023-011$ 